\title{
Cellulomonas terrae sp. nov., a cellulolytic and xylanolytic bacterium isolated from soil
}

\author{
Dong-Shan An, Wan-Taek Im, Hee-Chan Yang, Myung Suk Kang, \\ Kwang Kyu Kim, Long Jin, Myung Kyum Kim and Sung-Taik Lee
}

Correspondence

Sung-Taik Lee

e_stlee@kaist.ac.kr
Department of Biological Sciences, Korea Advanced Institute of Science and Technology (KAIST), Guseong-dong 373-1, Yuseong-gu, Daejeon 305-701, Republic of Korea
Polysaccharide-degrading enzymes such as amylase, cellulase and xylanase are widespread in nature. They can be found in every type of organism, including mammals, plants, algae, moulds, bacteria and phages (Oshima et al., 2002; Sutherland, 1999; Terra \& Ferreira, 1994). For the production of polysaccharases, micro-organisms are usually the most convenient sources and they can be obtained from various natural environments.

During a study of the bacterial community that produces polysaccharases, a large number of novel bacterial strains were isolated (Kang et al., 2003) from soil near the Korean city of Daejeon. On the basis of 16S RNA sequence data, one of these isolates, designated strain $\mathrm{DB}^{\mathrm{T}}$, was found to be a member of the genus Cellulomonas in the suborder Micrococcineae and was subjected to taxonomic investigation.

The aim of this study was to determine the taxonomic position of strain $\mathrm{DB} 5^{\mathrm{T}}$ by using chemotaxonomic, physiological and DNA-DNA hybridization analyses. The results provided evidence that $\mathrm{DB}^{\mathrm{T}}$ is a representative of a novel bacterial species.

Published online ahead of print on 1 April 2005 as DOI 10.1099/ ijs.0.63696-0.

The GenBank/EMBL/DDBJ accession number for the 16S rRNA gene sequence of strain $\mathrm{DB}^{\top}$ is $\mathrm{AY} 884570$.

Results of two-dimensional TLC analysis of polar lipids of strain DB5 ${ }^{\top}$ are available as supplementary material in IJSEM Online.
Strain $\mathrm{DB}^{\mathrm{T}}$ was isolated using the plate technique together with an insoluble chromogenic substrate (Ten et al., 2004). After isolation, strain $\mathrm{DB} 5^{\mathrm{T}}$ was cultivated by being transferred on R2A agar (Difco) every month. Cell morphology and motility were observed under a Nikon E600 light microscope $(1000 \times$ magnification $)$ using cells grown on R2A agar for 3 days at $30^{\circ} \mathrm{C}$. Growth at different temperatures and $\mathrm{pH}$ values was assessed after 5 days incubation. Salt tolerance was tested in R2A broth (Difco) supplemented with $1-10 \%(\mathrm{w} / \mathrm{v}) \mathrm{NaCl}$ after 5 days incubation. Growth was estimated by monitoring the $\mathrm{OD}_{600}$ value. Anaerobic growth was observed in serum bottles by adding thioglycolate $\left(1 \mathrm{~g} \mathrm{l}^{-1}\right)$ to R2A broth and substituting the upper air layer with nitrogen gas. Carbon-source utilization and some enzyme activities were tested by using API 20NE, API ID 32 and API $50 \mathrm{CH}$ test kits (bioMérieux). Catalase activity was determined by using $3 \%(\mathrm{v} / \mathrm{v}) \mathrm{H}_{2} \mathrm{O}_{2}$, while oxidase activity was determined using $1 \%(\mathrm{w} / \mathrm{v})$ tetramethyl $p$-phenylenediamine (Acros). Degradation of DNA (using DNA agar from Difco, supplemented with $0.01 \%$ toluidine blue from Merck), degradation of casein, cellulose and starch (Atlas, 1993), degradation of lipid (Kouker \& Jaeger, 1987) and degradation of xylan (Ten et al., 2004) were also investigated; reactions were read after 5 days. Duplicate antibiotic-sensitivity tests were done using filter-paper discs containing the following: streptomycin $(5,10$ and $15 \mu \mathrm{g})$, tetracycline $(5,10$ and $15 \mu \mathrm{g})$, kanamycin $(1 \cdot 0,1 \cdot 5$ and $2 \cdot 0 \mathrm{mg})$ and ampicillin $(20,25$ and $30 \mu \mathrm{g}$ ) (all from Sigma). Discs were placed on R2A plates 
Table 1. Comparison of selected characteristics of $C$. terrae sp. nov. $\mathrm{DB}^{\top}{ }^{\top}$ with those of its nearest phylogenetic neighbours in the genus Cellulomonas

Taxa: 1, C. terrae sp. nov. DB5 ${ }^{\mathrm{T}}$; 2, C. xylanilytica; 3, C. humilata; 4, Cellulomonas cellasea; 5, Cellulomonas biazotea; 6, Cellulomonas fimi; 7, Cellulomonas hominis. Data for taxa 1-3 are from this study; data for taxa 4-7 are from Rivas et al. (2004). Symbols: +, positive; (+), positive, weak or delayed response; - , negative; ND, not determined.

\begin{tabular}{|c|c|c|c|c|c|c|c|}
\hline Characteristic & 1 & 2 & 3 & 4 & 5 & 6 & 7 \\
\hline Motility & - & - & - & - & + & + & + \\
\hline Catalase & - & + & - & + & + & + & + \\
\hline \multicolumn{8}{|l|}{ Growth on: } \\
\hline Acetate & - & - & - & + & + & - & ND \\
\hline Gluconate & - & - & + & - & - & - & + \\
\hline Lactose & + & + & + & - & + & + & + \\
\hline Lactate & - & - & - & + & + & + & $\mathrm{ND}$ \\
\hline Mannose & + & + & + & + & + & + & ND \\
\hline Rhamnose & $(+)$ & + & + & - & + & + & + \\
\hline Mannitol & - & - & + & + & - & - & - \\
\hline \multicolumn{8}{|l|}{ Hydrolysis of: } \\
\hline Cellulose & + & + & + & + & + & + & $\mathrm{ND}$ \\
\hline Xylan & + & + & + & ND & $\mathrm{ND}$ & $\mathrm{ND}$ & ND \\
\hline Lipid & - & - & - & $\mathrm{ND}$ & $\mathrm{ND}$ & ND & $\mathrm{ND}$ \\
\hline Casein & - & - & - & $\mathrm{ND}$ & $\mathrm{ND}$ & $\mathrm{ND}$ & $\mathrm{ND}$ \\
\hline Starch & + & + & - & $\mathrm{ND}$ & $\mathrm{ND}$ & $\mathrm{ND}$ & $\mathrm{ND}$ \\
\hline Peptidoglycan composition & L-Orn-D-Glu & L-Orn-D-Glu & L-Orn-D-Glu & L-Orn-D-Glu & L-Orn-D-Glu & L-Orn-D-Glu & L-Orn \\
\hline Cell-wall sugars ${ }^{\star}$ & Rha, Gal, Glc & Rha, Man, Fuc & Rha, Fuc, Glc & Rha, Man, 6dTal & $\begin{array}{l}\text { Rha, Man, Gal, } \\
\text { 6dTal }\end{array}$ & Rha, Fuc, Glc & $\mathrm{ND}$ \\
\hline $\begin{array}{l}\text { Predominant cellular fatty } \\
\text { acids }\end{array}$ & $\begin{array}{l}\text { anteiso- } \mathrm{C}_{15: 0} \\
\text { iso- } \mathrm{C}_{15: 0} \\
\mathrm{C}_{16: 0}\end{array}$ & $\begin{array}{l}\text { anteiso- } \mathrm{C}_{15: 0} \\
\text { iso- } \mathrm{C}_{15: 0} \\
\mathrm{C}_{18: 0}\end{array}$ & $\begin{array}{l}\text { anteiso- } \mathrm{C}_{15: 0} \\
\text { anteiso- } \mathrm{C}_{17: 0} \\
\mathrm{C}_{16: 0}\end{array}$ & $\begin{array}{l}\text { anteiso- } \mathrm{C}_{15: 0}, \mathrm{C}_{16: 0} \\
\text { anteiso- } \mathrm{C}_{17: 0}\end{array}$ & $\begin{array}{l}\text { anteiso- } \mathrm{C}_{15: 0} \\
\text { iso- } \mathrm{C}_{15: 0} \\
\mathrm{C}_{16: 0}\end{array}$ & $\begin{array}{l}\text { anteiso- } \mathrm{C}_{15: 0}, \mathrm{C}_{16: 0} \text {, } \\
\text { anteiso- } \mathrm{C}_{17: 0}\end{array}$ & $\begin{array}{l}\text { anteiso- } C_{15: 0}, C_{16: 0}, \\
\text { anteiso- } C_{17: 0}\end{array}$ \\
\hline DNA G $+\mathrm{C}$ content $(\mathrm{mol} \%)$ & $73 \cdot 9$ & 73 & $\mathrm{ND}$ & 75 & $71 \cdot 5-75 \cdot 6$ & $71 \cdot 3-72 \cdot 0$ & 76 \\
\hline
\end{tabular}

*6dTal, 6-Deoxytalose; Fuc, fucose; Gal, galactose, Glc, glucose; Man, mannose; Rha, rhamnose. 
spread with $\mathrm{DB} 5^{\mathrm{T}}$ culture and were then incubated at $30^{\circ} \mathrm{C}$ for 5 days. The physiological and biochemical characteristics of strain $\mathrm{DB}^{\mathrm{T}}$ and related type strains are summarized in Table 1.

Extraction of genomic DNA, PCR-mediated amplification of the 16S rRNA gene and sequencing of the purified PCR product were carried out according to Im et al. (2004). The 16S rRNA gene partial sequences were compiled using SeqMan software; the 16S rRNA gene sequences of the test strain and related taxa (obtained from GenBank) were edited using the BioEdit program (Hall, 1999). Multiple alignments were performed by using the CLUSTAL_X program (Thompson et al., 1997). Evolutionary distances were calculated using the Kimura two-parameter model (Kimura, 1983). A phylogenetic tree was constructed by using the neighbour-joining method (Saitou \& Nei, 1987) in the MEGA2 program (Kumar et al., 2001). Bootstrap analysis with 1000 replicates was performed to obtain the confidence level of the branches (Felsenstein, 1985). All 12 species in the genus Cellulomonas were included in the phylogenetic tree.

Purified cell-wall preparations were obtained as described by Schleifer \& Kandler (1972). Amino acids and peptides in cell-wall hydrolysates were analysed with two-dimensional TLC on cellulose plates using solvent systems described by Schleifer \& Kandler (1972) and cell-wall sugar analysis as described by Staneck \& Roberts (1974). Menaquinone was extracted from cells grown on R2A broth and analysed as described by Komagata \& Suzuki (1987), using reversephase HPLC. Cellular fatty acids were analysed in organisms grown on trypticase soy agar (Difco) for 2 days. The cellular fatty acids were saponified, methylated, extracted and identified by the Microbial Identification software package (Sasser, 1990). Polar lipids were extracted and examined by using two-dimensional TLC (Minnikin et al., 1984).

The $\mathrm{G}+\mathrm{C}$ content of the chromosomal DNA was determined as described by Mesbah et al. (1989), using reversephase HPLC. DNA-DNA hybridization was performed fluorometrically according to the method of Ezaki et al. (1989), using photobiotin-labelled DNA probes (Sigma) and microdilution wells (Greiner). Hybridization was performed with five replications for each sample. The highest and lowest values obtained for each sample were excluded and the means of the remaining three values are quoted as DNA hybridization values.

The cells of strain $\mathrm{DB}^{\mathrm{T}}$ were found to be Gram-positive, non-motile, straight rods that were $0 \cdot 3-0 \cdot 6 \mu \mathrm{m}$ in diameter and $1 \cdot 6-2 \cdot 3 \mu \mathrm{m}$ in length. Colonies on R2A agar were yellow and smooth with clear edges. The strain showed negative results for catalase and oxidase activity, it was aerobic or facultatively anaerobic and it could reduce nitrate and hydrolyse aesculin, DNA, xylan and starch. The strain grew at $10-37^{\circ} \mathrm{C}$ but not at 4 or $45^{\circ} \mathrm{C}$; the optimum temperature was $30^{\circ} \mathrm{C}$. Growth was observed at $\mathrm{pH}$ values in the range $6 \cdot 5-9 \cdot 0$, the optimum $\mathrm{pH}$ being from $7 \cdot 0$ to $8 \cdot 0$. Strain $\mathrm{DB}^{\mathrm{T}}$ showed salt tolerance of $4 \%(\mathrm{w} / \mathrm{v}) \mathrm{NaCl}$.
Details of various differentiating characteristics of strain $\mathrm{DB} 5^{\mathrm{T}}$ and of phylogenetically related species are shown in Table 1; other characteristics are given in the species description.

The peptidoglycan composition of strain $\mathrm{DB}^{\mathrm{T}}$ corresponded to type A4 $\beta$; it contained L-ornithine-D-glutamic acid, which is reported for most members of the genus Cellulomonas and has been emphasized as an important feature for delineation, at genus level, in the Actinobacteria (Stackebrandt \& Schumann, 2000). In the case of Cellulomonas humilata ATCC $25174^{\mathrm{T}}$, Gledhill \& Casida (1969) found that the peptidoglycan of this strain contained lysine and ornithine. However, in our study, the determination of peptidoglycan for C. humilata ATCC $25174^{\mathrm{T}}$ showed the presence of L-ornithine-D-glutamic acid, which corresponds with the results of Stackebrandt et al. (2002); furthermore, the latter composition is found in most Cellulomonas species, including Cellulomonas xylanilytica LMG $21723^{\mathrm{T}}$. The cell-wall sugars of strain $\mathrm{DB}^{\mathrm{T}}$ were galactose, glucose and rhamnose. Fatty acid profiles of the strain and its closest neighbours are shown in Table 2. The major fatty acids were anteiso- $\mathrm{C}_{15: 0}(51.9 \%)$, iso- $\mathrm{C}_{15: 0}$ $(13 \cdot 3 \%)$ and $\mathrm{C}_{16: 0}(10 \cdot 9 \%)$. No significant differences in the fatty acid profiles were found with respect to the other Cellulomonas species. HPLC analysis of the menaquinones revealed two peaks: the main peak corresponded to MK- $9\left(\mathrm{H}_{4}\right)$ and the smaller one to MK- $8\left(\mathrm{H}_{4}\right)$. In addition, the major menaquinone found in members of the family Cellulomonadaceae is MK-9 $\left(\mathrm{H}_{4}\right)$. The polar lipids detected were diphosphatidylglycerol, phosphatidylethanolamine, phosphatidylglycerol, phosphatidylinositol mannosides and other unidentified phosphoglycolipids. The results of

Table 2. Cellular fatty acid composition of strain $\mathrm{DB} 5^{\top}$ and related type strains

Taxa: 1, C. terrae $\mathrm{DB}^{\mathrm{T}}$; 2. C. xylanilytica; 3. C. humilata. Fatty acids that account for less than $0.5 \%$ of the total fatty acid content in all strains are not shown; -, not detected.

\begin{tabular}{|c|c|c|c|}
\hline Fatty acid & 1 & 2 & 3 \\
\hline $\mathrm{C}_{14: 0}$ & $3 \cdot 6-3 \cdot 8$ & $4 \cdot 6-4 \cdot 8$ & $1 \cdot 0-1 \cdot 8$ \\
\hline$C_{16: 0}$ & $8 \cdot 0-9 \cdot 5$ & $9 \cdot 5-10 \cdot 6$ & $11 \cdot 2-12 \cdot 8$ \\
\hline $\mathrm{C}_{17: 0}$ & $1 \cdot 8-2 \cdot 3$ & $1 \cdot 8-2 \cdot 7$ & $1 \cdot 2-2 \cdot 1$ \\
\hline $\mathrm{C}_{18: 0}$ & $7 \cdot 1-8 \cdot 2$ & $10 \cdot 7-13 \cdot 0$ & $0 \cdot 8-1 \cdot 8$ \\
\hline iso- $\mathrm{C}_{14: 0}$ & $5 \cdot 1-5 \cdot 9$ & $7 \cdot 7-9 \cdot 6$ & $7 \cdot 8-8 \cdot 9$ \\
\hline iso- $\mathrm{C}_{15: 0}$ & $15 \cdot 2-18 \cdot 5$ & $18 \cdot 6-22 \cdot 1$ & $10 \cdot 9-12 \cdot 2$ \\
\hline anteiso- $\mathrm{C}_{15: 0}$ & $44 \cdot 5-45 \cdot 6$ & $40 \cdot 1-45 \cdot 5$ & $32 \cdot 8-44 \cdot 9$ \\
\hline anteiso- $\mathrm{C}_{15: 1} \mathrm{~A}$ & - & $1 \cdot 9-2 \cdot 6$ & $2 \cdot 4-3 \cdot 3$ \\
\hline iso- $\mathrm{C}_{16: 0}$ & - & $1 \cdot 8-2 \cdot 3$ & $1 \cdot 7-7 \cdot 0$ \\
\hline iso- $\mathrm{C}_{17: 0}$ & - & - & $0 \cdot 8-1 \cdot 6$ \\
\hline anteiso- $\mathrm{C}_{17: 0}$ & $7 \cdot 4-7 \cdot 6$ & $5 \cdot 5-6 \cdot 6$ & $11 \cdot 6-13 \cdot 7$ \\
\hline Unknown $14 \cdot 258^{\star}$ & $2 \cdot 9-3 \cdot 4$ & $3 \cdot 0-3 \cdot 3$ & $1 \cdot 2-2 \cdot 7$ \\
\hline
\end{tabular}

${ }^{*}$ Unknown $14 \cdot 258$ represents an unknown peak that appeared at $14 \cdot 258 \mathrm{~min}$. 


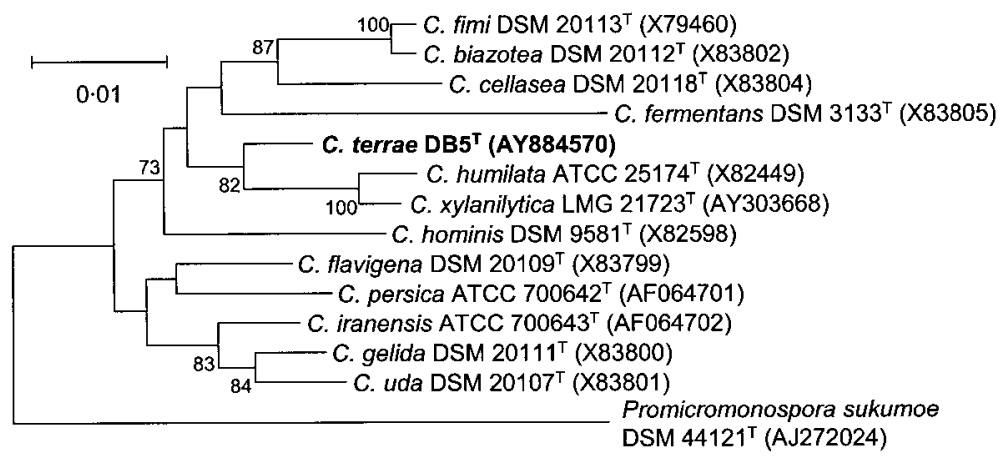

Fig. 1. Rooted phylogenetic tree based on the 16S rRNA gene sequences of the proposed species C. terrae sp. nov. $\mathrm{DB}^{\top}{ }^{\top}$ and its closest phylogenetic neighbours. This tree was made using the neighbour-joining method (Saitou \& Nei, 1987) with a Kimura two-parameter distance matrix and pairwise deletion. Bootstrap values (expressed as percentages of 1000 replications) greater than $70 \%$ are shown at branch points. Bar, 10 substitutions per 1000 nt.

polar lipid analysis of strain $\mathrm{DB}^{\mathrm{T}}$ are available as supplementary data in IJSEM Online.

The almost-complete $16 \mathrm{~S}$ rRNA gene sequence (1475 bp) of strain $\mathrm{DB} 5^{\mathrm{T}}$ was compared with $16 \mathrm{~S}$ rRNA gene sequences from the GenBank database, with the aid of the BLASTN program (Altschul et al., 1990) and the Ribosomal Database Project (Maidak et al., 1997). The two species most closely related to strain $\mathrm{DB}^{\mathrm{T}}$ were found to be C. xylanilytica LMG $21723^{\mathrm{T}}(98 \cdot 0 \%)$ and C. humilata ATCC $25174^{\mathrm{T}}$ (97.9\%). A phylogenetic tree obtained by using the neighbour-joining method shows this close relationship (Fig. 1), which was supported by a high bootstrap value based on 1000 resamplings. Furthermore, the results of DNA-DNA hybridization showed that strain $\mathrm{DB} 5^{\mathrm{T}}$ has $41 \%$ relatedness with C. xylanilytica LMG $21723^{\mathrm{T}}$ and $20 \%$ relatedness with C. humilata ATCC $25174^{\mathrm{T}}$. These results suggest that strain $\mathrm{DB}^{\mathrm{T}}$ should be classified as a novel species, particularly in view of the recommendations of Wayne et al. (1987) and Stackebrandt \& Goebel (1994) for species delineation. The DNA G $+\mathrm{C}$ content of the strain is $73.9 \mathrm{~mol} \%$, a value that falls within the range reported for members of the genus Cellulomonas.

In summary, the characteristics of strain $\mathrm{DB}^{\mathrm{T}}$ are consistent with descriptions of the genus Cellulomonas with regard to morphological, biochemical and chemotaxonomic properties. The characteristics also supported the conclusion inferred from the 16S rRNA gene sequence analysis, i.e. that strain $\mathrm{DB}^{\mathrm{T}}$ belongs to the genus Cellulomonas. However, some biochemical reactions and physiological characteristics differentiate strain $\mathrm{DB}^{\mathrm{T}}$ from any Cellulomonas species with validly published names, and DNA-DNA hybridization confirmed that this strain represents a taxonomically distinct species. On the basis of these results, $\mathrm{DB}^{\mathrm{T}}\left(=\mathrm{KCTC} 19081^{\mathrm{T}}=\right.$ NBRC $\left.100819^{\mathrm{T}}\right)$ is proposed as the type strain of a novel species of the genus Cellulomonas, namely Cellulomonas terrae sp. nov.

\section{Description of Cellulomonas terrae sp. nov.}

Cellulomonas terrae (ter'rae. L. gen. n. terrae of the earth).

Grows well under aerobic or facultatively anaerobic conditions at $30^{\circ} \mathrm{C}$ on R2A agar. Cells are Gram-positive, straight rods and produce creamy yellow, circular, smooth colonies. No growth at 4 or $45^{\circ} \mathrm{C}$ or at $4 \% \mathrm{NaCl}$. Shows negative results for oxidase and catalase activity and production of urease, indole and acylamidase, and positive results for $\beta$-galactosidase, $\beta$-glucosidase, reduction of nitrate and hydrolysis of aesculin, DNA, starch and xylan. Can also use the following as sole carbon sources: arabinose, cellulose, fructose, galactose, gentiobiose, glycogen, glucose, inositol, 5-ketogluconate, maltose, mannose, D-melibiose, $\mathrm{N}$-acetylglucosamine, rhamnose, D-sucrose, starch and xylan. Shows no growth with the following: acetate, adipate, L-alanine, caprate, citrate, L-fucose, gluconate, 3hydroxybenzoate, 3-hydroxybutyrate, 4-hydroxybutyrate, histidine, itaconate, 2-ketogluconate, lactate, mannitol, malate, malonate, propionate, L-proline, phenylacetate, Dribose, salicin, L-serine, D-sorbitol, suberate and valerate. Can produce acid from L-arabinose, cellobiose, fructose, galactose, gentiobiose, glycerol, glycogen, glucose, Dlyxose, maltose, mannose, melezitose, melibiose, $\mathrm{N}$ acetylglucosamine, raffinose, sucrose, trehalose, D-turanose and D-xylose. It is also resistant to discs containing $30 \mu \mathrm{g}$ ampicillin, $15 \mu \mathrm{g}$ tetracycline, $15 \mu \mathrm{g}$ streptomycin and $2 \mathrm{mg}$ kanamycin. The predominant isoprenoid quinones are MK-9 $\left(\mathrm{H}_{4}\right)$ and MK-8 $\left(\mathrm{H}_{4}\right)$. The most abundant cellular fatty acids are anteiso- $\mathrm{C}_{15: 0}(51 \cdot 9 \%)$, iso- $\mathrm{C}_{15: 0}(13 \cdot 3 \%)$ and $\mathrm{C}_{16: 0}(10 \cdot 9 \%)$. The $\mathrm{G}+\mathrm{C}$ content of the genomic DNA of the type strain is $73.9 \mathrm{~mol} \%$. The peptidoglycan contains L-Orn-D-Glu (type A4 $\beta$ ). The cell-wall sugars are galactose, glucose and rhamnose.

The type strain, $\mathrm{DB}^{\mathrm{T}}\left(=\right.$ KCTC $\left.19081^{\mathrm{T}}=\mathrm{NBRC} 100819^{\mathrm{T}}\right)$, was isolated from soil near Yusong in Daejeon City, Republic of Korea.

\section{Acknowledgements}

This work was supported by Eco-Tecnopia-21, Ministry of Environment, Gwacheon, Korea (grant 121-041-028) and by the 21C Frontier Microbial Genomics and Application Center Program, Ministry of Science \& Technology (grant MG05-0101-4-0), Republic of Korea.

\section{References}

Altschul, S. F., Gish, W., Miller, W., Myers, E. W. \& Lipman, D. J. (1990). Basic local alignment search tool. J Mol Biol 215, 403-410. 
Atlas, R. M. (1993). Handbook of Microbiological Media. Edited by L. C. Parks. Boca Raton, FL: CRC Press.

Ezaki, T., Hashimoto, Y. \& Yabuuchi, E. (1989). Fluorometric deoxyribonucleic acid-deoxyribonucleic acid hybridization in microdilution wells as an alternative to membrane filter hybridization in which radioisotopes are used to determine genetic relatedness among bacterial strains. Int J Syst Bacteriol 39, 224-229.

Felsenstein, J. (1985). Confidence limit on phylogenies: an approach using the bootstrap. Evolution 39, 783-791.

Gledhill, W. E. \& Casida, L. E., Jr (1969). Predominant catalasenegative soil bacteria. II. Occurrence and characterization of Actinomyces humiferus, sp. n. Appl Microbiol 18, 114-121.

Hall, T. A. (1999). BioEdit: a user-friendly biological sequence alignment editor and analysis program for Windows 95/98/NT. Nucleic Acids Symp Ser 41, 95-98.

Im, W. T., Bae, H. S., Yokota, A. \& Lee, S.-T. (2004). Herbaspirillum chlorophenolicum sp. nov., a 4-chlorophenol-degrading bacterium. Int J Syst Evol Microbiol 54, 851-855.

Kang, M. S., Im, W.-T., Ten, L. N. \& Lee, S.-T. (2003). Isolation and diversity of bacteria having extracellular degrading enzymes of xylan and/or amylose and/or cellulose. In Proceedings of the International Meeting of the Federation of Korean Microbiological Societies 2003, abstract B4022, p. 165. Seoul: The Microbiological Society of Korea. Kimura, M. (1983). The Neutral Theory of Molecular Evolution. Cambridge: Cambridge University Press.

Komagata, K. \& Suzuki, K. (1987). Lipid and cell wall analysis in bacterial systematics. Methods Microbiol 19, 161-207.

Kouker, G. \& Jaeger, K.-E. (1987). Specific and sensitive plate assay for bacterial lipases. Appl Environ Microbiol 53, 211-213.

Kumar, S., Tamura, K., Jacobsen, I.-B. \& Nei, M. (2001). MEGA2: molecular evolutionary genetics analysis software. Bioinformatics $\mathbf{1 7}$, 1244-1245.

Maidak, B. L., Olsen, G. J., Larsen, N., Overbeek, R., McCaughey, M. J. \& Woese, C. R. (1997). The RDP (Ribosomal Database Project). Nucleic Acids Res 25, 109-111.

Mesbah, M., Premachandran, U. \& Whitman, W. B. (1989). Precise measurement of the $\mathrm{G}+\mathrm{C}$ content of deoxyribonucleic acid by highperformance liquid chromatography. Int J Syst Bacteriol 39, 159-167.

Minnikin, D. E., O'Donnell, A. G., Goodfellow, M., Alderson, G., Athalye, M., Schaal, K. \& Parlett, J. H. (1984). An integrated procedure for the extraction of isoprenoid quinones and polar lipids. J Microbiol Methods 2, 233-241.

Oshima, H., Miyazaki, R., Ohe, Y., Hayashi, H., Kawamura, K. \& Kikuyama, S. (2002). Isolation and sequence of a novel amphibian pancreatic chitinase. Comp Biochem Physiol Part B Biochem Mol Biol 132, 381-388.
Rivas, R., Trujillo, M. E., Mateos, P. F., Martínez-Molina, E. \& Velázquez, E. (2004). Cellulomonas xylanilytica sp. nov., a cellulolytic and xylanolytic bacterium isolated from a decayed elm tree. Int J Syst Evol Microbiol 54, 533-536.

Saitou, N. \& Nei, M. (1987). The neighbor-joining method: a new method for reconstructing phylogenetic trees. Mol Biol Evol 4, 406-425.

Sasser, M. (1990). Identification of bacteria by gas chromatography of cellular fatty acids. MIDI Technical Note 101. Newark, DE: MIDI.

Schleifer, K. H. \& Kandler, O. (1972). Peptidoglycan types of bacterial cell walls and their taxonomic implications. Bacteriol Rev 36, 407-477.

Stackebrandt, E. \& Goebel, B. M. (1994). Taxonomic note: a place for DNA-DNA reassociation and $16 \mathrm{~S}$ rRNA sequence analysis in the present species definition in bacteriology. Int J Syst Bacteriol 44, 846-849.

Stackebrandt, E. \& Schumann, P. (2000). Description of Bogoriellaceae fam. nov., Dermacoccaceae fam. nov., Rarobacteraceae fam. nov. and Sanguibacteraceae fam. nov. and emendation of some families of the suborder Micrococcineae. Int J Syst Evol Microbiol 50, 1279-1285.

Stackebrandt, E., Breymann, S., Steiner, U., Prauser, H., Weiss, N. \& Schumann, P. (2002). Re-evaluation of the status of the genus Oerskovia, reclassification of Promicromonospora enterophila (Jáger et al. 1983) as Oerskovia enterophila comb. nov. and description of Oerskovia jenensis sp. nov. and Oerskovia paurometabola sp. nov. Int J Syst Evol Microbiol 52, 1105-1111.

Staneck, J. L. \& Roberts, G. D. (1974). Simplified approach to identification of aerobic actinomycetes by thin-layer chromatography. Appl Microbiol 28, 226-231.

Sutherland, I. W. (1999). Polysaccharases for microbial exopolysaccharides. Carbohydr Polym 38, 319-328.

Ten, L. N., Im, W.-T., Kim, M.-K., Kang, M.-S. \& Lee, S.-T. (2004). Development of a plate technique for screening of polysaccharidedegrading microorganisms by using a mixture of insoluble chromogenic substrates. J Microbiol Methods 56, 375-382.

Terra, W. R. \& Ferreira, C. (1994). Insect digestive enzymes: properties, compartmentalization and function. Comp Biochem Physiol Part B Biochem Mol Biol 109, 1-62.

Thompson, J. D., Gibson, T. J., Plewniak, F., Jeanmougin, F. \& Higgins, D. G. (1997). The CLUSTAL_X Windows interface: flexible strategies for multiple sequence alignment aided by quality analysis tools. Nucleic Acids Res 25, 4876-4882.

Wayne, L. G., Brenner, D. J., Colwell, R. R. \& 9 other authors (1987). International Committee on Systematic Bacteriology. Report of the ad hoc committee on reconciliation of approaches to bacterial systematics. Int J Syst Bacteriol 37, 463-464. 